\title{
Article \\ Human $\beta$-Defensin 2 (HBD-2) Displays Oncolytic Activity but Does Not Affect Tumour Cell Migration
}

\author{
Guneet K. Bindra, Scott A. Williams, Fung T. Lay (D), Amy A. Baxter, Ivan K. H. Poon, Mark D. Hulett *(D) \\ and Thanh Kha Phan *(D)
}

Citation: Bindra, G.K.; Williams, S.A.; Lay, F.T.; Baxter, A.A.; Poon, I.K.H.; Hulett, M.D.; Phan, T.K. Human $\beta$-Defensin 2 (HBD-2) Displays Oncolytic Activity but Does Not Affect Tumour Cell Migration. Biomolecules 2022, 12, 264. https:// doi.org/10.3390/biom12020264 Academic Editor: Mark S. Johnson

Received: 26 November 2021 Accepted: 3 February 2022

Published: 6 February 2022

Publisher's Note: MDPI stays neutral with regard to jurisdictional claims in published maps and institutional affiliations.

Copyright: (C) 2022 by the authors. Licensee MDPI, Basel, Switzerland. This article is an open access article distributed under the terms and conditions of the Creative Commons Attribution (CC BY) license (https:// creativecommons.org/licenses/by/ $4.0 /)$.
Department of Biochemistry and Genetics, La Trobe Institute for Molecular Science, La Trobe University, Melbourne, VIC 3086, Australia; g.bindra@latrobe.edu.au (G.K.B.); scott.williams@latrobe.edu.au (S.A.W.); f.lay@latrobe.edu.au (F.T.L.); a.baxter@latrobe.edu.au (A.A.B.); i.poon@latrobe.edu.au (I.K.H.P.)

* Correspondence: M.Hulett@latrobe.edu.au (M.D.H.); Thanh.Phan@latrobe.edu.au (T.K.P.)

\begin{abstract}
Defensins form an integral part of the cationic host defence peptide (HDP) family, a key component of innate immunity. Apart from their antimicrobial and immunomodulatory activities, many HDPs exert multifaceted effects on tumour cells, notably direct oncolysis and/or inhibition of tumour cell migration. Therefore, HDPs have been explored as promising anticancer therapeutics. Human $\beta$ defensin 2 (HBD-2) represents a prominent member of human HDPs, being well-characterised for its potent pathogen-killing, wound-healing, cytokine-inducing and leukocyte-chemoattracting functions. However, its anticancer effects remain largely unknown. Recently, we demonstrated that HBD-2 binds strongly to phosphatidylinositol-4,5-bisphosphate $\left(\mathrm{PI}(4,5) \mathrm{P}_{2}\right)$, a key mediator of defensin-induced cell death and an instructional messenger during cell migration. Hence, in this study, we sought to investigate the lytic and anti-migratory effects of HBD-2 on tumour cells. Using various cell biological assays and confocal microscopy, we showed that HBD-2 killed tumour cells via acute lytic cell death rather than apoptosis. In addition, our data suggested that, despite the reported $\mathrm{PI}(4,5) \mathrm{P}_{2}$ interaction, HBD-2 does not affect cytoskeletal-dependent tumour cell migration. Together, our findings provide further insights into defensin biology and informs future defensin-based drug development.
\end{abstract}

Keywords: defensin; host defence peptide; tumour; cell death; cell migration

\section{Introduction}

Defensins, a group of cysteine-containing, $\beta$-sheet-rich, cationic HDPs, are important contributors to innate immunity, providing crucial infection-combating mechanisms [1,2]. Despite the varying primary sequence, the tertiary structure of defensins remains relatively similar across different kingdoms, suggesting an evolutionarily conserved mechanism of action [3]. Initially discovered for their potent antimicrobial activity, defensins have recently gained increased interest due to their functional complexity, among which are tumour-suppressing effects [4-6]. Defensins have, therefore, emerged as a potential new class of multifaceted therapeutic agents [7].

Several plant and human defensins such as Nicotiana alata defensin 1, NaD1, Nicotiana occidentalis defensin, NoD173, tomato defensin TPP3 and human $\beta$-defensin HBD-3, selectively target tumour cell membranes and rapidly induce the formation of large, irreversible membrane blebs followed by cell lysis. The defensin-induced oncolysis is mediated by their interaction with membrane phosphoinositides, particularly phosphatidylinositol4,5-bisphosphate $\left(\mathrm{PI}(4,5) \mathrm{P}_{2}\right)$ through a conserved cluster of positively-charged amino acids [4,8-10]. In contrast, human neutrophil peptide 1 (HNP-1, an $\alpha$-defensin) and human $\beta$-defensin HBD-1 induce apoptosis, a form of non-lytic programmed cell death, in prostate adenocarcinoma and bladder cancer cells, respectively [11,12]. In vivo studies have shown that NoD173 is effective in arresting mouse melanoma growth in a xenograft tumour model [4]. In addition, defensins can also prevent tumour cell migration via the disruption 
of cytoskeleton dynamics. For example, PvD1 defensin (from common bean Phaseolus vulgaris) effectively disturbs the cytoskeleton of breast cancer cells, thus perturbing cell-to-cell adhesion and tumour cell migration [13]. Human $\beta$-defensins HBD-1 and HBD-3 also exhibit modulatory activity against actin regulators such as Rho family proteins, vascular endothelial growth factor (VEGF) and metastasis-associated 1 family member 2 (MTA2), resulting in anti-migratory effects against oral squamous cell carcinoma [14,15], head and neck [16] and colon cancer cells [17]. Of note, phosphoinositides, especially $\mathrm{PI}(4,5) \mathrm{P}_{2}$, are particularly instrumental in initiating/maintaining cell polarity and cascading cytoskeletal signalling required for cell migration [18]. It is, therefore, of interest to determine whether $\mathrm{PI}(4,5) \mathrm{P}_{2}$-binding defensins could suppress tumour cell migration, in addition to direct tumour cell lysis.

Human $\beta$-defensin 2 (HBD-2) is a potent antiviral, antibacterial and antifungal HDP, and is also capable of potentiating immune responses [19-22]. HBD-2 acts as a chemoattractant for dendritic cells, $\mathrm{T}$ cells and monocytes, is a chemokine receptor CCR2/CCR6dependent manner [23-26]. Therefore, HBD-2 was proposed as an antiviral and anti-colitis agent as well as a vaccine adjuvant $[19,21]$. In contrast to the well-studied antimicrobial and immune-modulating properties, the effects of HBD-2 on tumour cells are still poorly characterised. Indeed, there are only a few expression studies to date, and these have simply correlated the endogenous HBD-2 level to tumour cell proliferation and invasion, suggesting opposing effects depending on the cancer setting. Therefore, based on our reported interaction between HBD-2 and $\mathrm{PI}(4,5) \mathrm{P}_{2}$ [27], we aimed to assess the action of HBD-2 against tumour cells by investigating the oncolytic and anti-migratory effects of endogenous HBD-2. Here, our cell biological and confocal microscopy data reveal that HBD-2 kills tumour cells via an acute, non-apoptotic, membrane blebbing-associated cell lysis mechanism. In addition, HBD-2 does not appear to affect actin-dependent tumour cell migration, despite the reported $\mathrm{PI}(4,5) \mathrm{P}_{2}$ binding. Together, our findings provide further insights into defensin biology and inform future defensin-based drug development.

\section{Materials and Methods}

\subsection{Expression of HBD-2 in Pichia pastoris}

HBD-2 was recombinantly expressed in the methylotrophic yeast Pichia pastoris (GS115) and purified using SP-Sepharose cationic exchange chromatography, as previously described [28].

\subsection{Cell Lines and Cultures}

Human epithelial cervical cancer (HeLa) and leukemic monocytic lymphoma (U937) cells were cultured in RPMI-1640 (Invitrogen, Carlsbad, CA, USA) media supplemented with $5-10 \%(v / v)$ foetal calf serum (FCS), $100 \mathrm{U} / \mathrm{mL}$ penicillin and $100 \mu \mathrm{g} / \mathrm{mL}$ streptomycin (Invitrogen). Mouse embryonic fibroblast (MEF) and MEF Bax/Bak knockout cells were a kind gift from the Puthalakath lab at La Trobe University [29] and cultured in DMEMF12 (Invitrogen) supplemented with 10\% $(v / v)$ FCS, $100 \mathrm{U} / \mathrm{mL}$ penicillin and $100 \mu \mathrm{g} / \mathrm{mL}$ streptomycin. Human breast adenocarcinoma (MDA-MB-231) and basal cell carcinoma (BCC) cells were cultured in DMEM (Invitrogen) supplemented with 10\% $(v / v)$ FCS, $100 \mathrm{U} / \mathrm{mL}$ penicillin and $100 \mu \mathrm{g} / \mathrm{mL}$ streptomycin. Breast adenocarcinoma (MCF-7) cells were cultured in EMEM (Sigma-Aldrich, St. Louis, MI, USA) with 10\% (v/v) FCS, 100 U/mL penicillin and $100 \mu \mathrm{g} / \mathrm{mL}$ streptomycin. All cell lines were cultured at $37^{\circ} \mathrm{C}$ in a humidified atmosphere containing $5 \% \mathrm{CO}_{2}$.

\subsection{Cell Viability Assay}

Different concentrations of HBD-2 $(0-50 \mu \mathrm{M})$ were added to pre-optimised cell densities for each cell line $\left(1 \times 10^{5}\right.$ cells $\left./ \mathrm{mL}\right)$ in 96 -well plates in an appropriate complete medium. Following $48 \mathrm{~h}$ incubation with HBD-2, cell viability was determined using MTT and MTS reagents as previously described [10]. 


\subsection{Propidium Iodide (PI) Uptake Assay}

Cells at $1 \times 10^{6}$ cells $/ \mathrm{mL}$ in serum-free medium containing $0.1 \%(w / v)$ bovine serum albumin (BSA) (Sigma-Aldrich) were treated with varying concentrations of HBD-2 at $37^{\circ} \mathrm{C}$ for $30 \mathrm{~min}$, as previously described [10]. Cells were subjected to flow cytometry analysis using BD FACSCanto II Flow Cytometer and BD FACSDiva Software v8.8.10 (BD Biosciences, San Jose, CA, USA).

\subsection{ATP Bioluminescence Assay}

ATP release assay was conducted using an ATP bioluminescence assay kit (Roche Diagnostics, Mannheim, Germany). U937 and HeLa cells were suspended at $1 \times 10^{6}$ cells $/ \mathrm{mL}$ in PBS containing $0.1 \%(w / v)$ BSA and mixed with luciferase/luciferin reagent at a ratio of 4:5. The mixture was added to HBD-2 samples and the level of ATP release was measured immediately as bioluminescence emission signal intensity for $30 \mathrm{~min}$ with $30 \mathrm{~s}$ intervals.

\subsection{Lipid Inhibition Assay}

HBD-2 $(25 \mu \mathrm{M})$ or PBS was incubated with $10 \mu \mathrm{M}$ phosphatidic acid (PA), phosphatidylinositol-3,5-bisphosphate $\left(\mathrm{PI}(3,5) \mathrm{P}_{2}\right)$ or phosphatidylinositol-4,5-bisphosphate $\left(\mathrm{PI}(4,5) \mathrm{P}_{2}\right)$ (Avanti Polar Lipids, Birmingham, AL, USA) on ice for $30 \mathrm{~min}$, followed by flow cytometry-based PI uptake assay with U937 cells.

\subsection{Caspase-Glo Assay}

Caspase-Glo 3/7 assay reagent (Promega, Madison, WI, USA) was used to detect caspase activation in vitro. U937 and HeLa cells were seeded at $1 \times 10^{5}$ cells $/ \mathrm{mL}$, followed by treatment with HBD-2 $(25 \mu \mathrm{M})$ for $30 \mathrm{~min}$. Caspase-Glo reagent was added in 1:1 ratio, incubated in dark for $1 \mathrm{~h}$ at RT, followed by measuring luminescence.

\subsection{Confocal Laser Scanning Microscopy (CSLM)}

Live imaging was performed on a Zeiss LSM-780 confocal microscope using a $63 \times$ oil immersion objective in a $37^{\circ} \mathrm{C}$ incubator with $5 \% \mathrm{CO}_{2}$. Adherent HeLa cells were cultured overnight on coverslips while suspension U937 cells were immobilised onto $0.01 \%(w / v)$ poly-L-lysine-coated coverslips. Both cell types were prepared in serum-free RPMI 1640 medium containing $0.1 \%(w / v)$ BSA and $2 \mu \mathrm{g} / \mathrm{mL}$ PI. HBD-2 was added to directly to the imaging chamber to final concentration of $25 \mu \mathrm{M}$. Excitation and emission wavelengths were $488 \mathrm{~nm}$ and $514 \mathrm{~nm}$ (for green channel, PKH67), and $514 \mathrm{~nm}$ and $633 \mathrm{~nm}$ (for red channel, PI), respectively.

Cytoskeletal microscopy was performed on a Zeiss LSM-800 confocal microscope (Zeiss, Jena, Germany) using a $63 \times$ oil immersion objective in a $37^{\circ} \mathrm{C}$ incubator with $5 \%$ $\mathrm{CO}_{2}$. Adherent MDA-MB-231 cells were cultured overnight with SiR-actin or SiR-tubulin in serum-free RPMI 1640 medium containing $0.1 \%(w / v)$ BSA. HBD-2 $(5 \mu \mathrm{M})$, cytochalasin $\mathrm{D}(10 \mu \mathrm{M})$ and nocodazole $(20 \mu \mathrm{M})$ were added directly to the imaging chamber via a capillary tube. Excitation and emission wavelengths were $514 \mathrm{~nm}$ and $633 \mathrm{~nm}$ for the red channel, respectively. Cytoskeletal microscopy was quantified using relative cell surface area on Fiji/ImageJ software (GNU General Public License).

\subsection{Transwell Cell Migration Assay}

Serum-free MDA-MB-231 cells were seeded at $2.5 \times 10^{5}$ cells $/ \mathrm{mL}$ on the inserts of Corning $6.5 \mathrm{~mm}$ transwell with $8.0 \mu \mathrm{m}$ pore polycarbonate transwell plates (Corning, NY, USA). Cells were incubated for $1 \mathrm{~h}$ at $37^{\circ} \mathrm{C}, 5 \% \mathrm{CO}_{2}$ prior to treatment with nocodazole $(20 \mu \mathrm{M})$, cytochalasin $\mathrm{D}(10 \mu \mathrm{M})$ or HBD-2 $(5 \mu \mathrm{M})$ in serum-free DMEM to the insert with the cells. Serum-free or serum-DMEM were added to lower wells and the cells were incubated for 6 or $24 \mathrm{~h}$ at $37^{\circ} \mathrm{C}, 5 \% \mathrm{CO}_{2}$. Migrated cells were fixed with $70 \%$ ethanol for $10 \mathrm{~min}$ at RT, followed by staining with $0.2 \%$ crystal violet for $10 \mathrm{~min}$ at RT. Membrane inserts were imaged using Olympus BX41 microscope and Olympus DP25 camera, with $4 \times$ (data not shown) and $10 \times$ oil immersion objective lenses, followed by absorbance 
reading of the stain dissolved with $10 \%(v / v)$ acetic acid at $590 \mathrm{~nm}$. Relative migration was measured by the migration index, denoted by the following equation:

$$
\text { Migration index }=\frac{\text { Treatment }- \text { no FCS control }}{\text { FCS }- \text { no FCS control }}
$$

\section{Results}

\subsection{HBD-2 Induces Tumour Lytic Cell Death, Independent of Apoptosis}

To determine the anti-tumour activity of HBD-2, tetrazolium-based cell viability assays were performed. We found that in a dose-dependent manner, HBD-2 killed various tumour cell lines, including cervical cancer cells (HeLa), prostate cancer cells (PC3), breast cancer cells (MCF-7 and BCC) with $\mathrm{IC}_{50}$ of $\geq 50 \mu \mathrm{M}$, with minimal cytotoxic effects against monocytic lymphoma cells (U937) and metastatic breast carcinoma cells (MDA-MB-231) (Figure 1a).

As $\mathrm{PI}(4,5) \mathrm{P}_{2}$-binding defensins can induce lytic cell death, characterised by large membrane blebbing and membrane permeabilisation, we investigated the ability of HBD-2 to lyse tumour cells. First, flow cytometry analysis was conducted using propidium iodide (PI) as a membrane permeabilisation indicator. We observed moderate, dose-dependent levels of membrane permeabilisation, with PI positivity sitting at 10-30\% in most tested cells lines at $50 \mu \mathrm{M}$ HBD-2, except for MDA-MB-231 (at only 5\%) (Figure 1b). To complement the PI uptake assay and to study the kinetics of oncolysis, we also performed an ATP release bioluminescence assay on the tumour cell lines. Indeed, HBD-2-treated HeLa cells (Figure 1c) and, to a lesser extent, U937 cells (Figure 1d) significantly showed detectable bioluminescence signals in a time-dependent fashion, suggesting the leakage of cytosolic ATP due to oncolysis. To confirm the relevance of HBD-2-lipid interaction in oncolysis, flow cytometry-based PI uptake analysis was performed with HBD-2 pre-treated with PI $(4,5)_{2}$ (implicated in defensin-induced oncolysis), $\mathrm{PI}(3,5) \mathrm{P}_{2}$ (same charge as $\mathrm{PI}(4,5)_{2}$ but higher affinity) and PA (non-binder) [27]. Among all tested lipids, only PI(4,5) $\mathrm{P}_{2}$ significantly reduced HBD-2 activity on HeLa cells (Figure 1e).

To investigate a possible role for apoptosis in the anti-tumour cell activity of HBD2, we repeated the tetrazolium-based cell viability and PI uptake assays using Bax/Bak double-knockout MEF cells. Compared to the wild-type control, the deficiency of the proapoptotic proteins Bax and Bak did not impair HBD-2-induced cytotoxicity and cytolysis, indicating a non-apoptotic mechanism for HBD-2 activity (Figure 1f). Consistently, unlike apoptosis-inducing BH3 mimetics, apoptotic caspases 3/7 were not activated upon HBD-2 treatment over $30 \mathrm{~min}$ or $48 \mathrm{~h}$ periods (Figure $1 \mathrm{~g}, \mathrm{~h}$ ).

Next, we performed confocal laser scanning microscopy to visualise HBD-2-induced oncolysis. Intriguingly, HBD-2-treated HeLa and U937 cells display characteristic lytic morphologies, evident by strong PI positivity, loss of cell integrity and formation of large membrane blebs (Figure 2a). Time-course images of HBD-2 treated U937 were also captured to provide an overview of HBD-2 mediated cell permeabilisation (Figure $2 b$ ). The addition of HBD-2 rapidly led to the formation of membrane blebbing and detection of slight PI staining, indicating an early sign of membrane permeabilisation (01:00 min). A flashing expulsion of cellular content was then observed in these cells, as indicated by a flux of nucleic acid extracellularly, which was immediately stained by PI-containing medium in a few seconds. The subsequent damage to the plasma cell membrane then leads to the increased PI influx, and thus enhanced red fluorescent signal. 


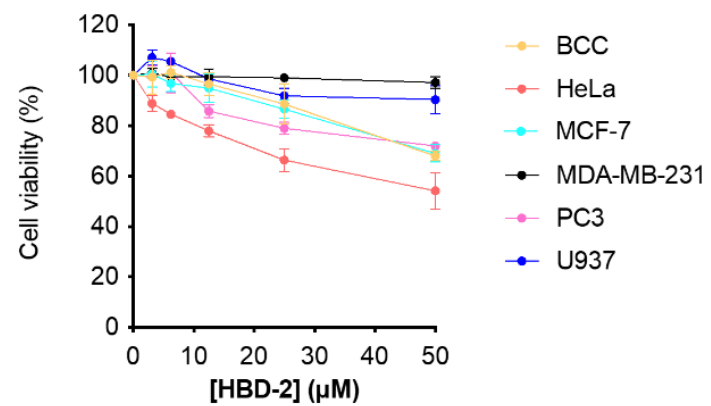

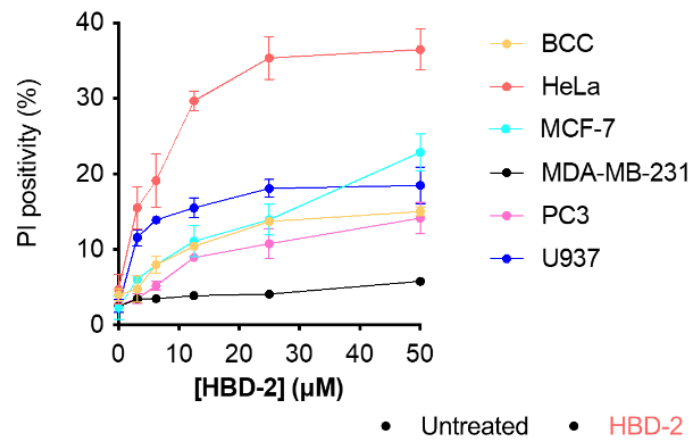

e

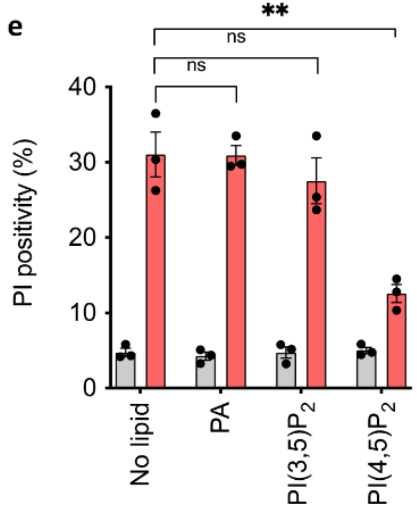

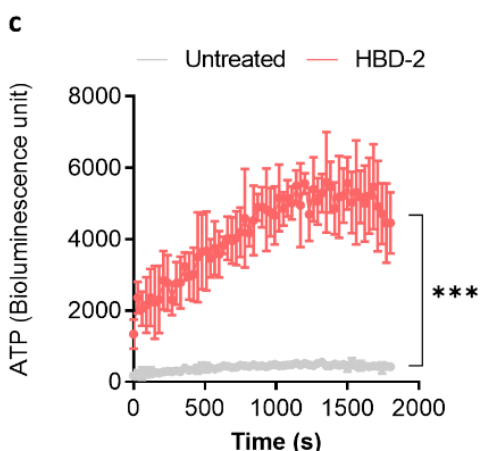

f

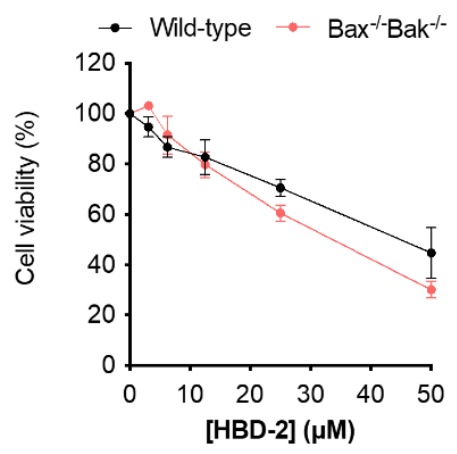

d

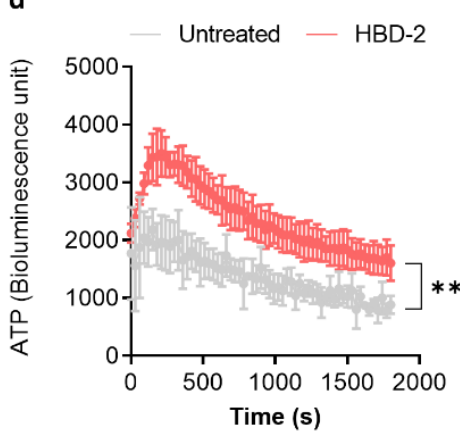

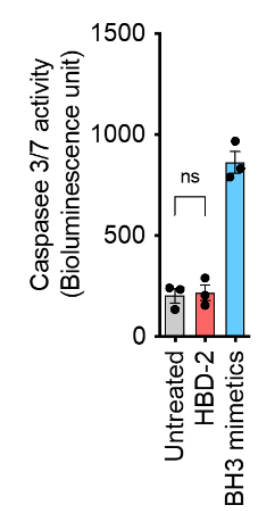

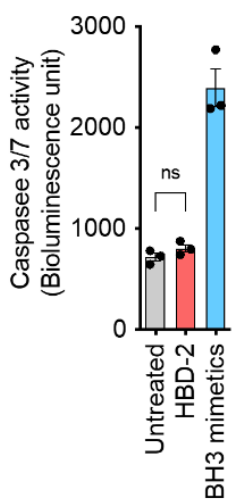

Figure 1. HBD-2 induces tumour cell death in a non-apoptotic manner. (a) Dose-dependent reduction in cell viability of different tumour cell lines (BCC, HeLa, MCF-7, MDA-MB-231, PC3 and U937) determined by tetrazolium-based assay. Data normalised against untreated control, which was arbitrarily assigned $100 \%$ viability. (b) Flow cytometry-based PI uptake assay on tumourigenic BCC, HeLa, MCF-7, MDA-MB-231, PC3 and U937 cells. The level of permeabilisation was expressed as PI positivity. ATP bioluminescence assay of HeLa (c) and U937 (d) cells treated with HBD-2 (50 $\mu \mathrm{M})$ titrations. The level of ATP released was detected as bioluminescence emission signal intensity. Data represent mean \pm SEM of three independent experiments. ${ }^{* *} p<0.01,{ }^{* * *} p<0.001$; Two-way ANOVA. (e) Flow cytometry-based PI uptake assay on HBD-2 or PBS pre-incubated with $\mathrm{PA}, \mathrm{PI}(3,5) \mathrm{P}_{2}$ or $\mathrm{PI}(4,5) \mathrm{P}_{2}$ lipids on U937 cells. ${ }^{* *} p<0.01$, ns: not significant; unpaired $t$-test. (f) Dose-dependent reduction in cell viability of MEF wild-type and MEF Bax/Bak double knockout cells. Caspase-Glo 3/7 activity assay on U937 (g) and HeLa (h) cells treated with HBD-2 or BH3 mimetics over 30 min. Data represent the mean \pm SEM of three independent experiments. ns: not significant; unpaired t-test. 

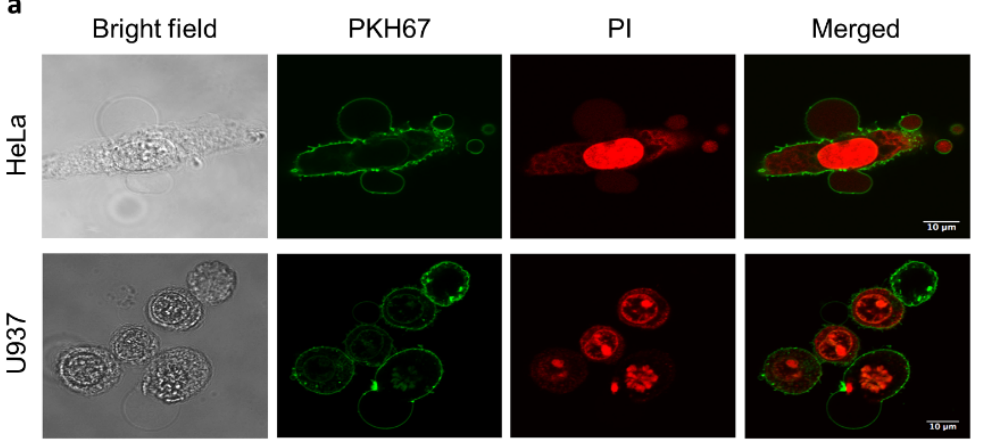

b

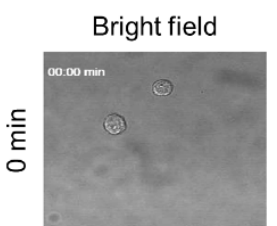

PKH67
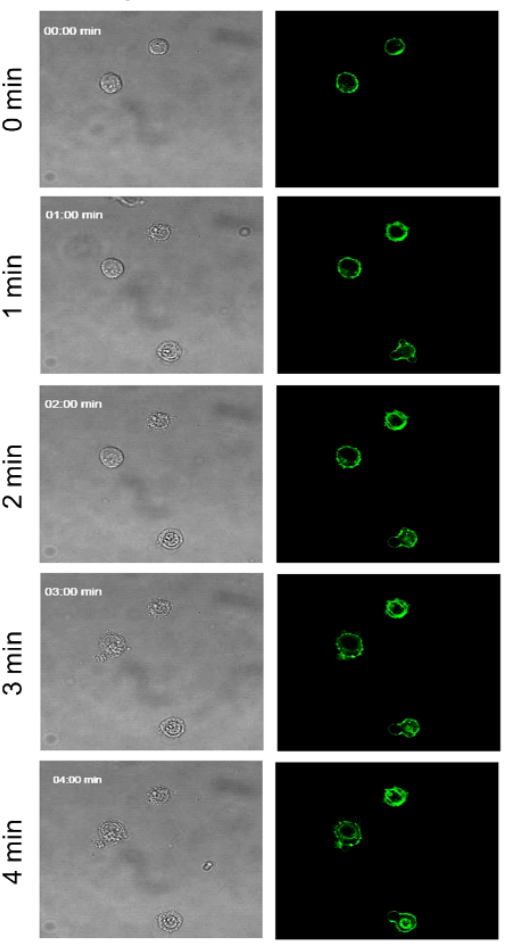
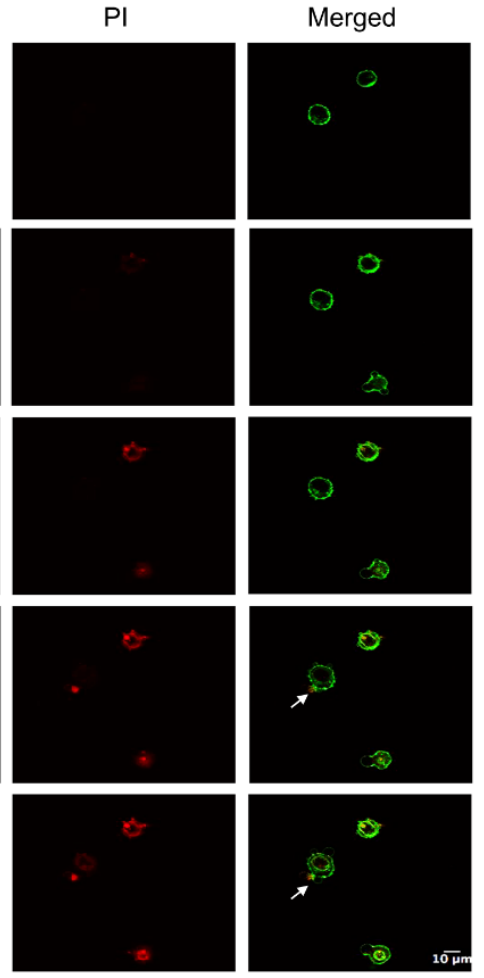

Figure 2. Kinetics of HBD-2-induced tumour cell death. (a) CLSM of HBD-2 (25 $\mu \mathrm{M})$ treated HeLa and U937 cells, in the presence of PI and membrane stain PKH67. Images were taken 5 min post addition of HBD-2. (b) CLSM of HBD-2 (25 $\mu \mathrm{M})$ on the kinetics of U937 cell permeabilisation. PI-positive staining and membrane blebbing occur $1 \mathrm{~min}$ post-HBD-2 addition, followed by the release of intracellular content (indicated by white arrows). Data representatives of three independent experiments. Scale bars represent $10 \mu \mathrm{m}$.

\subsection{HBD-2 Does Not Affect Cytoskeleton-Dependent Tumour Cell Migration}

Many defensins, such as PvD1, HBD-1 and HBD-3 have been shown to perturb tumour cell migration, often via the disruption of cytoskeleton dynamics $[13,14,17,30]$. Since $\mathrm{PI}(4,5) \mathrm{P}_{2}$ and other phosphoinositides are pivotal signalling messengers orchestrating the cell migration machinery, we, therefore, sought to determine whether the $\mathrm{PI}(4,5) \mathrm{P}_{2}$-binding defensin HBD-2 could suppress tumour cell migration. To this end, a transwell migration assay was conducted on human metastatic breast cancer cells MDA-MB-231, with FBS as the migratory stimulus. Unlike cytochalasin D (actin polymerisation inhibitor) and nocodazole (tubulin inhibitor) treatments, which are known to block cell migration [31], HBD-2 did not affect FCS-induced MDA-MB-231 migration over $6 \mathrm{~h}$ or $24 \mathrm{~h}$ period (Figure 3a-c). Similar results were also observed for PC3 cells (Figure S1). Furthermore, whilst cytochalasin D and nocodazole caused drastic changes in actin network and microtubules, respectively, 
with a significant reduction in relative cell surface area post-treatment, HBD-2 had little effect on these cytoskeleton elements even after $24 \mathrm{~h}$ (Figure $3 \mathrm{~d}-\mathrm{g}$ ).

a
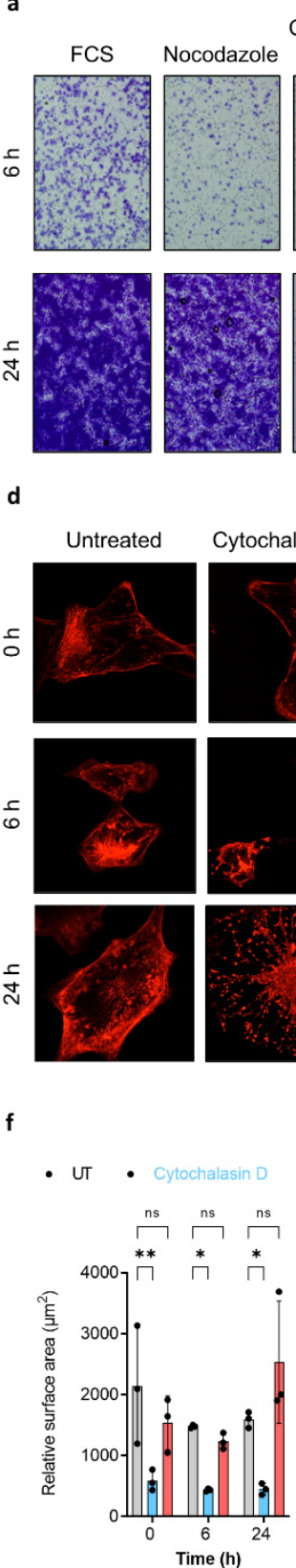

b
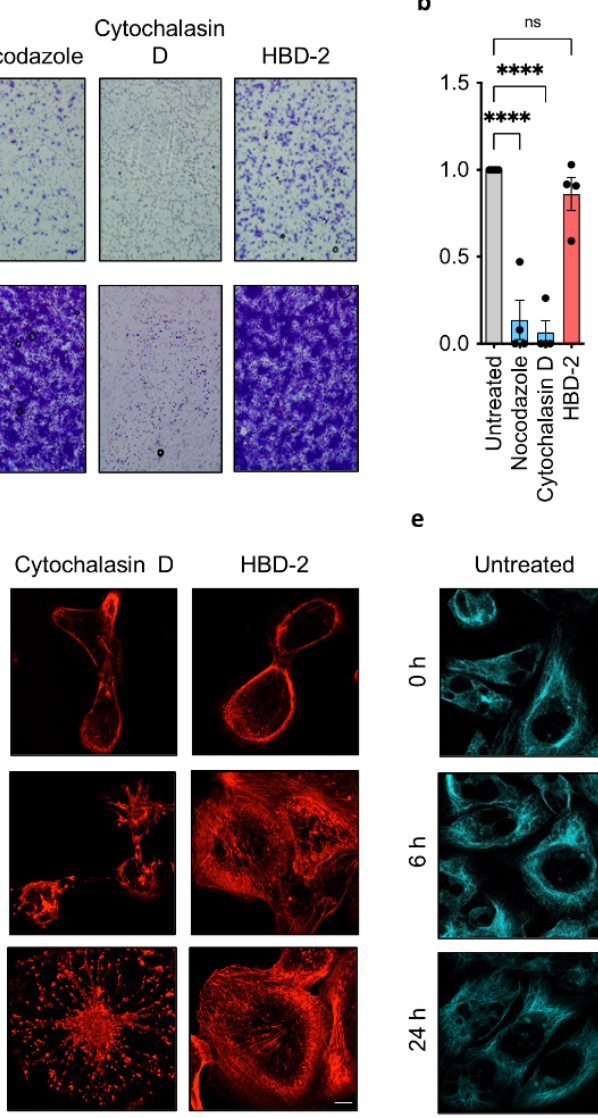
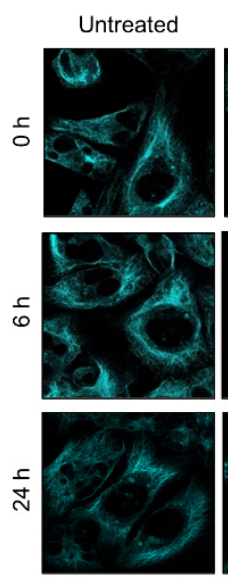

g

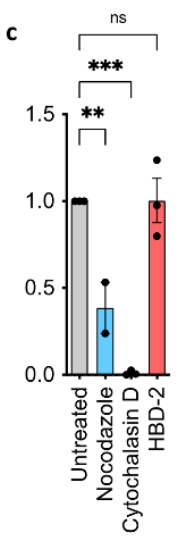

Nocodazole
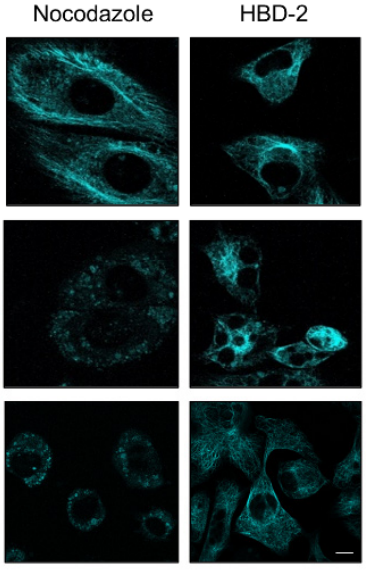

Figure 3. Effect of HBD-2 on tumour cell migration. (a) Microscopic images of MDA-MB-231 cells taken over 6 and $24 \mathrm{~h}$ representing migrated cells (purple) following various treatments (FCS, nocodazole, cytochalasin D and HBD-2). Quantitative analysis of membranes from a., over $6 \mathrm{~h} \mathrm{(b)}$ and $24 \mathrm{~h}$ (c), with all data normalised to No FCS control. Data represent mean \pm SEM of at least three independent experiments. ${ }^{* *} p<0.01,{ }^{* * *} p<0.001$, ${ }^{* * * *} p<0.0001$, ns: not significant; One-way ANOVA. CLSM of MDA-MB-231 cells stained with SiR-Actin (d) and SiR-tubulin (e) and imaged over $24 \mathrm{~h}$ with HBD-2 $(5 \mu \mathrm{M})$, cytochalasin D $(10 \mu \mathrm{M})$ and nocodazole $(20 \mu \mathrm{M})$. Quantification of CLSM with a relative surface area of actin $(\mathbf{f})$ and tubulin $(\mathbf{g})$ Data represents mean \pm SEM of at least three independent experiments. ${ }^{*} p<0.05,{ }^{* *} p<0.01,{ }^{* * *} p<0.001$, ns: not significant; Two-way ANOVA. Scale bars represent $10 \mu \mathrm{m}$. 


\section{Discussion}

The multifunctionality and broad-spectrum activities against pathogens and tumour cells of many defensins and HDPs present increasing clinical interest. Their functional complexities, however, also pose certain challenges for defensin-based drug development and require a comprehensive understanding of defensin biology. HBD-2, a prominent defensin with potent immune-modulating and antimicrobial properties, has been explored as a vaccine adjuvant and anti-infective agent [19,27,32-35]. Nevertheless, unlike other defensins, its therapeutic applicability in cancer settings remains poorly studied. Based on the strong interaction of HBD-2 to membrane $\mathrm{PI}(4,5) \mathrm{P}_{2}$ lipid, we aimed to investigate the effect of HBD-2 on tumour cell-related $\mathrm{PI}(4,5) \mathrm{P}_{2}$-mediated processes, namely oncolysis and tumour migration.

Our study demonstrated that HBD-2 displays moderate cytotoxic effects against various tumour cells. To this end, HBD-2 effectively triggers membrane lysis, ultimately leading to tumour cell death, which resembles necrosis rather than apoptosis. These findings are consistent with the oncolytic activity of the plant defensin NaD1 [36]. Furthermore, as similarly reported for HBD-3 [10], only pre-treatment with $\mathrm{PI}(4,5) \mathrm{P}_{2}$, not the equally charged and stronger binder $\mathrm{PI}(3,5) \mathrm{P}_{2}$, substantially impaired HBD-2-induced tumour cell lysis. Biophysical studies (such as X-ray crystallography) with HBD-2 and PI(4,5) $\mathrm{P}_{2}$ showed the intricate nature of the interaction, with two $\mathrm{PI}(4,5) \mathrm{P}_{2}$ molecules bound to HBD-2. Mutations in the cationic residues of HBD-2, specifically K25 and K36, sequestered lipid binding and antifungal activity. This provides insight into the membrane destabilising nature of HBD2-PI $(4,5) \mathrm{P}_{2}$ interaction, providing further support for the acute lytic nature of HBD-2 [27]. Although it remains to be defined how HBD-2 and other defensins enter tumour cells, it was demonstrated that electrostatic interaction between defensins and membrane phospholipids led to membrane perturbation, the formation of necrotic blebs and eventually cell death $[5,6,18]$. Together, our findings provide further evidence for a novel conserved oncolytic mechanism among defensins [10] and emphasises the importance of targeting phosphoinositide in cell death [18].

Increased levels of phosphoinositides, particularly $\mathrm{PI}(4,5) \mathrm{P}_{2}$, are well-reported during tumourigenesis [37-39]. $\mathrm{PI}(4,5) \mathrm{P}_{2}$, through its diverse effectors, is essential for tumour cell polarity, epithelial-to-mesenchymal transition, invasion and metastasis through the recruitment of focal adhesion proteins and actin polymerisation effectors [38,40,41]. $\mathrm{PI}(4,5) \mathrm{P}_{2}$-producing enzymes phosphatidylinositol 5-phosphate 4-kinase (PIP4K) and phosphatidylinositol 4-phosphate 5-kinase type 1 alpha (PIP5KI $\alpha$ ) are also overexpressed in various cancers, such as triple-negative breast cancers, HER2-positive breast cancer, advanced prostate cancer and luminal ER+ cancer [42-48]. In these tumour settings, $\mathrm{PI}(4,5) \mathrm{P}_{2}$ generated by PIP4K and PIP5KI $\alpha$ act upstream of and thus promote PI3K-Akt signalling, which is crucial for cancer growth and survival [47,49-51]. As the apparent determinant of HBD-2-mediated oncolysis, one can speculate that the level of plasma membrane $\mathrm{PI}(4,5) \mathrm{P}_{2}$ (and potentially other phosphoinositides), which is likely to vary among different tumour cells, dictates the HBD-2 potency. For example, cervical cancer HeLa cells containing $\sim 8 \%$ phosphoinositides, compared to $2 \%$ in U937 cells [52,53], may lead to the greater HBD-2 susceptibility, as we observed in this study. In addition, multiple physical changes of plasma membranes upon tumour transformation could also have contributed to the susceptibility to defensin-induced oncolysis [54]. Due to an upregulation of negatively charged membrane components (e.g., O-glycosylated mucins [55,56] and heparan sulfate proteoglycans [57]) and the breakdown of membrane asymmetry (e.g., phosphatidylserine externalization $[58,59])$, tumour cells have an increased negative charge on their membranes, thus contributing to initial electrostatic interaction of defensins, such as HBD-2, to tumour cell surface. Other factors, such as increased surface area $[60,61]$ and increased fluidity from reduced membrane cholesterol [62,63], further make tumour cells more susceptible to the activity of defensins. Nevertheless, the precise mechanisms of differential sensitivity of different tumour cells towards HBD-2 and other defensins remain to be determined. 
Of note, the anti-tumour activity of HBD-2 $(\geq 50 \mu \mathrm{M})$ was lower than that reported for other plant and human defensins, such as NaD1 $(\sim 2-7 \mu \mathrm{M})$ and HBD-3 ( 10-20 $\mu \mathrm{M})[10,36]$, as well as its own antimicrobial activities $(\sim 1-4 \mu \mathrm{M})[27,34,64]$. As the net positive charge is one of the key determinants of HDP anti-tumour activity and defensin-phospholipid interaction $[5,40,65,66]$, the lower net positive charge of HBD-2 (net charge of +6 ) could be responsible for it being less potent than HBD-3 (net charge of +11 ). Although HBD-2 and $\mathrm{NaD} 1$ have a similar net charge $(+6)$, differences in binding affinity and/or charge distribution between HBD-2-PI(4,5) $\mathrm{P}_{2}$ and $\mathrm{NaD} 1-\mathrm{PI}(4,5) \mathrm{P}_{2}$ could contribute to the differential activity of the two defensins $[8,27]$. In contrast, the presence of other membrane and cell wall moieties, such as glucosylceramide in fungal cells may make microbial cells more susceptible to HBD-2 [67].

In contrast to many other defensins such as HBD-1, HBD-3 and PvD1 [13,14,17,30], HBD-2 does not appear to affect tumour cell migration. Often, through various mechanisms, defensins perturb the cytoskeleton, a key component of the cell migration machinery, and are orchestrated by phosphoinositide signalling. However, this was not observed for HBD-2. It is tempting to speculate whilst HBD-2 can bind $\mathrm{PI}(4,5) \mathrm{P}_{2}$, the HBD-2-PI $(4,5) \mathrm{P}_{2}$ binding interaction may be competed for by other $\mathrm{PI}(4,5) \mathrm{P}_{2}$-binding cytoskeletal proteins. Interestingly, HBD-2 has been reported to promote the chemotactic migration of immune cells and keratinocytes $[23,26]$. In addition to membrane phospholipids, HBD-2 may interact with other membrane targets that could mediate the migratory effect of HBD-2 on immune cells and keratinocytes. For example, HBD-2 may mediate cell migration in a $\mathrm{PI}(4,5) \mathrm{P}_{2}$-independent, CCR6-regulated manner, leading to F-actin accumulation [68]. Other pathways such as EGFR/STAT3 [23], VEGF signalling [24] and GPCR/ERK/JNK/p38 [25] may also play crucial roles in HBD-2 mediated cell migration. Thus, the binding of HBD-2 to $\mathrm{PI}(4,5) \mathrm{P}_{2}$ may not be the only determinant, as cell migration can occur in a $\mathrm{PI}(4,5) \mathrm{P}_{2^{-}}$ independent manner.

Overall, the low mammalian cell cytotoxic nature of HBD-2, along with its potent activity towards microbial cells, reassures the potential of HBD-2 as a less-toxic antiinfective therapeutics. The exploitation of HBD-2 for its potent antimicrobial and immunomodulatory activity in disease settings, such as experimental colitis, asthma and sepsis, demonstrates promising results, with the abrogation of disease, with minimal side effects in vivo $[21,22,69,70]$. Our data from PI uptake assay, ATP release assay, confocal microscopy and caspase activity assay consistently show that at high concentration, HBD-2 can rapidly permeabilise tumour cells and induce cell lysis, but not apoptotic cell death. The discrepancy between MTT and PI uptake/ATP release assay data may be attributed to several factors, particularly the presence of serum in the MTT assay, which is a major extrinsic factor impairing HBD-2 activity [71]. The presence of serum and serum proteases, especially during prolonged periods $(48 \mathrm{~h})$, may result in protein degradation, hence affecting the cytotoxic activity of HBD-2. Indeed, HBD-2 loses its antibacterial activity in the presence of $20 \%$ serum [33]. It is, therefore, reasonable to speculate that serum presence in MTT assay may also reduce the anticancer activity of HBD-2. However, whether HBD-2 should be explored for anticancer therapy, the modest anti-tumour effects of HBD-2 shown in our study suggests an effective peptide delivery and/or substantial peptide engineering would likely be required. Indeed, HBD-2 transfection induces oral carcinoma cell death and impaired tumour invasion [72], suggesting that HBD-2 may work more potently once delivered directly into tumour cells. In addition, a recombinantly engineered peptide derived from HBD-2 and oncolytic vaccinia virus significantly enhances anti-tumour immune response, inhibiting tumour growth [73], emphasising the importance of engineered HBD-2 for enhanced activity.

\section{Conclusions}

Together, our findings offer further insights into HBD-2 biology and support the concept of a non-apoptotic, oncolytic mechanism conserved in defensins. In addition, it also suggests that HBD-2 does not influence tumour cell migration in vitro. These findings 
on the anti-tumour cell effects of HBD-2 will help inform future defensin-based drug development.

Supplementary Materials: The following supporting information can be downloaded at https: / www. mdpi.com/article/10.3390/biom12020264/s1, Figure S1: Microscopic images of PC3 cell migration.

Author Contributions: G.K.B. and T.K.P. designed, conducted, and analysed the experiments. S.A.W., F.T.L., A.A.B., I.K.H.P. and M.D.H. provided resources and assistance with data analysis. I.K.H.P., T.K.P. and M.D.H. provided funds and supervised the project. G.K.B. and T.K.P. wrote the manuscript and all authors revised the original draft. All authors have read and agreed to the published version of the manuscript.

Funding: This work was supported by Australian Research Council Discovery Grant DP190103591.

Institutional Review Board Statement: Not applicable.

Informed Consent Statement: Not applicable.

Data Availability Statement: The data supporting this research is available upon request.

Acknowledgments: The authors thank the La Trobe University Bioimaging Facility for their thoughtful insights and discussions, as well as for assistance with technical difficulties.

Conflicts of Interest: The authors declare no conflict of interest.

\section{References}

1. Xu, D.; Lu, W. Defensins: A double-edged sword in host immunity. Front Immunol. 2020, 11, 764. [CrossRef] [PubMed]

2. Azmi, S.; Hussain, M.K. Analysis of structures, functions, and transgenicity of phytopeptides defensin and thionin: A review. Beni-Suef. Univ. J. Basic Appl. Sci. 2021, 10, 5. [CrossRef]

3. Shafee, T.M.A.; Lay, F.T.; Hulett, M.D.; Anderson, M.A. The defensins consist of two independent, convergent protein superfamilies. Mol. Biol. Evol. 2016, 33, 2345-2356. [CrossRef] [PubMed]

4. Lay, F.T.; Ryan, G.F.; Caria, S.; Phan, T.K.; Veneer, P.K.; White, J.A.; Kvansakul, M.; Hulett, M.D. Structural and functional characterization of the membrane-permeabilizing activity of Nicotiana occidentalis defensin NoD173 and protein engineering to enhance oncolysis. FASEB J. 2019, 33, 6470-6482. [CrossRef]

5. Baxter, A.A.; Lay, F.T.; Poon, I.K.H.; Kvansakul, M.; Hulett, M.D. Tumor cell membrane-targeting cationic antimicrobial peptides: Novel insights into mechanisms of action and therapeutic prospects. Cell Mol. Life Sci. 2017, 74, 3809-3825. [CrossRef]

6. Hein, M.J.A.; Kvansakul, M.; Lay, F.T.; Hulett, M.D. Defensin-Lipid interactions in membrane targeting: Mechanisms of action and opportunities for the development of antimicrobial and anticancer therapeutics. Biochem. Soc. Trans. 2022, BST20200884. [CrossRef]

7. Mookherjee, N.; Anderson, M.A.; Haagsman, H.P.; Davidson, D.J. Antimicrobial host defence peptides: Functions and clinical potential. Nat. Rev. Drug Discov. 2020, 19, 311-332. [CrossRef]

8. Poon, I.; A Baxter, A.; Lay, F.; Mills, G.D.; Adda, C.; Payne, J.; Phan, T.K.; Ryan, G.F.; A White, J.; Veneer, P.K.; et al Phosphoinositide-mediated oligomerization of a defensin induces cell lysis. elife 2014, 3, e01808. [CrossRef]

9. Baxter, A.A.; Richter, V.; Lay, F.; Poon, I.K.H.; Adda, C.; Veneer, P.K.; Phan, T.K.; Bleackley, M.; Anderson, M.A.; Kvansakul, M.; et al. The tomato defensin TPP3 binds phosphatidylinositol (4,5)-bisphosphate via a conserved dimeric cationic grip conformation to mediate cell lysis. Mol. Cell Biol. 2015, 35, 1964-1978. [CrossRef]

10. Phan, T.K.; Lay, F.T.; Poon, I.K.H.; Hinds, M.G.; Kvansakul, M.; Hulett, M.D. Human $\beta$-defensin 3 contains an oncolytic motif that binds $\mathrm{PI}(4,5) \mathrm{P}(2)$ to mediate tumour cell permeabilisation. Oncotarget 2016, 7, 2054-2069. [CrossRef]

11. Gaspar, D.; Freire, J.M.; Pacheco, T.R.; Barata, J.T.; Castanho, M.A.R.B. Apoptotic human neutrophil peptide-1 anti-tumor activity revealed by cellular biomechanics. Biochim. Biophys. Acta 2015, 1853, 308-316. [CrossRef] [PubMed]

12. Sun, C.Q.; Arnold, R.; Fernandez-Golarz, C.; Parrish, A.B.; Almekinder, T.; He, J.; Ho, S.-M.; Svoboda, P.; Pohl, J.; Marshall, F.F.; et al. Human $\beta$-defensin-1, a potential chromosome $8 \mathrm{p}$ tumor suppressor: Control of transcription and induction of apoptosis in renal cell carcinoma. Cancer Res. 2006, 66, 8542-8549. [CrossRef] [PubMed]

13. Figueira, T.N.; Oliveira, F.D.; Almeida, I.; Mello, O.; Gomes, V.M.; Castanho, M.A.R.B.; Gaspar, D. Challenging metastatic breast cancer with the natural defensin PvD1. Nanoscale 2017, 9, 16887-16899. [CrossRef] [PubMed]

14. Han, Q.; Wang, R.; Sun, C.; Jin, X.; Liu, D.; Zhao, X.; Wang, L.; Ji, N.; Li, J.; Zhou, Y.; et al. Human beta-defensin-1 suppresses tumor migration and invasion and is an independent predictor for survival of oral squamous cell carcinoma patients. PLOS ONE 2014, 9, e91867. [CrossRef]

15. Sawaki, K.; Mizukawa, N.; Yamaai, T.; Yoshimoto, T.; Nakano, M.; Sugahara, T. High concentration of $\beta$-defensin-2 in oral squamous cell carcinoma. Anticancer Res. 2002, 22, 2103-2107.

16. Wang, K.; Wang, J.H.; Baskaran, H.; Wang, R.; Jurevic, R. Effect of human beta-defensin-3 on head and neck cancer cell migration using micro-fabricated cell islands. Head Neck Oncol. 2012, 4, 41. [CrossRef] 
17. Uraki, S.; Sugimoto, K.; Shiraki, K.; Tameda, M.; Inagaki, Y.; Ogura, S.; Kasai, C.; Nojiri, K.; Yoneda, M.; Yamamoto, N.; et al. Human $\beta$-defensin-3 inhibits migration of colon cancer cells via downregulation of metastasis-associated 1 family, member 2 expression. Int. J. Oncol. 2014, 45, 1059-1064. [CrossRef]

18. Phan, T.K.; Williams, S.; Bindra, G.K.; Lay, F.T.; Poon, I.K.H.; Hulett, M.D. Phosphoinositides: Multipurpose cellular lipids with emerging roles in cell death. Cell Death Differ. 2019, 26, 781-793. [CrossRef]

19. Kim, J.; Yang, Y.L.; Jang, S.-H.; Jang, Y.-S. Human $\beta$-defensin 2 plays a regulatory role in innate antiviral immunity and is capable of potentiating the induction of antigen-specific immunity. Virol. J. 2018, 15, 124. [CrossRef]

20. Kandaswamy, K.; Liew, T.H.; Wang, C.Y.; Huston-Warren, E.; Meyer-Hoffert, U.; Hultenby, K.; Schröder, J.M.; Caparon, M.G.; Normark, S.; Henriques-Normark, B.; et al. Focal targeting by human $\beta$-defensin 2 disrupts localized virulence factor assembly sites in Enterococcus faecalis. Proc. Natl. Acad. Sci. USA 2013, 110, 20230-20235. [CrossRef]

21. Koeninger, L.; Armbruster, N.S.; Brinch, K.S.; Kjaerulf, S.; Andersen, B.; Langnau, C.; Autenrieth, S.E.; Schneidawind, D.; Stange, E.F.; Malek, N.P.; et al. Human $\beta$-defensin 2 mediated immune modulation as treatment for experimental colitis. Front. Immunol. 2020, 11, 93. [CrossRef] [PubMed]

22. Cieślik, M.; Bagińska, N.; Górski, A.; Jończyk-Matysiak, E. Human $\beta$-defensin 2 and its postulated role in modulation of the immune response. Cells 2021, 10, 2991. [CrossRef]

23. Mi, B.; Liu, J.; Liu, Y.; Hu, L.; Liu, Y.; Panayi, A.C.; Zhou, W.; Liu, G. The designer antimicrobial peptide A-hBD-2 facilitates skin wound healing by stimulating keratinocyte migration and proliferation. Cell Physiol. Biochem. 2018, 51, 647-663. [CrossRef]

24. Baroni, A.; Donnarumma, G.; Paoletti, I.; Longanesi-Cattani, I.; Bifulco, K.; Tufano, M.A.; Carriero, M.V. Antimicrobial human beta-defensin-2 stimulates migration, proliferation and tube formation of human umbilical vein endothelial cells. Peptides $\mathbf{2 0 0 9}$ 30, 267-272. [CrossRef] [PubMed]

25. Soruri, A.; Grigat, J.; Forssmann, U.; Riggert, J.; Zwirner, J. $\beta$-Defensins chemoattract macrophages and mast cells but not lymphocytes and dendritic cells: CCR6 is not involved. Eur. J. Immunol. 2007, 37, 2474-2486. [CrossRef]

26. Niyonsaba, F.; Ogawa, H.; Nagaoka, I. Human $\beta$-defensin-2 functions as a chemotactic agent for tumour necrosis factor- $\alpha$-treated human neutrophils. Immunology 2004, 111, 273-281. [CrossRef] [PubMed]

27. Järvå, M.; Phan, T.K.; Lay, F.T.; Caria, S.; Kvansakul, M.; Hulett, M.D. Human $\beta$-defensin 2 kills Candida albicans through phosphatidylinositol 4,5-bisphosphate-mediated membrane permeabilization. Sci. Adv. 2018, 4, eaat0979. [CrossRef]

28. Järvå, M.; Lay, F.T.; Hulett, M.D.; Kvansakul, M. Structure of the defensin NsD7 in complex with PIP2 reveals that defensin: Lipid oligomer topologies are dependent on lipid type. FEBS Lett. 2017, 591, 2482-2490. [CrossRef]

29. Srivastava, R.; Cao, Z.; Nedeva, C.; Naim, S.; Bachmann, D.; Rabachini, T.; Gangoda, L.; Shahi, S.; Glab, J.; Menassa, J.; et al. BCL-2 family protein BOK is a positive regulator of uridine metabolism in mammals. Proc. Natl. Acad. Sci. USA 2019, 116, 15469-15474. [CrossRef]

30. Xu, D.; Zhang, B.; Liao, C.; Zhang, W.; Wang, W.; Chang, Y.; Shao, Y. Human beta-defensin 3 contributes to the carcinogenesis of cervical cancer via activation of NF- $\mathrm{kB}$ signaling. Oncotarget 2016, 7, 75902-75913. [CrossRef]

31. Lee, K.; Song, K. Actin dysfunction activates ERK1/2 and delays entry into mitosis in mammalian cells. Cell Cycle 2007, 6, 1487-1495. [CrossRef] [PubMed]

32. Kim, J.; Yang, Y.; Jeong, Y.; Jang, Y.S. Conjugation of human $\beta$-defensin 2 to spike protein receptor-binding domain induces antigen-specific protective immunity against middle east respiratory syndrome coronavirus infection in human dipeptidyl peptidase 4 transgenic mice. Vaccines 2020, 8, 635. [CrossRef] [PubMed]

33. Mineshiba, F.; Takashiba, S.; Mineshiba, J.; Matsuura, K.; Kokeguchi, S.; Murayama, Y. Antibacterial activity of synthetic human B defensin-2 against periodontal bacteria. J. Int. Acad. Periodontol. 2003, 5, 35-40. [PubMed]

34. Routsias, J.G.; Karagounis, P.; Parvulesku, G.; Legakis, N.J.; Tsakris, A. In vitro bactericidal activity of human $\beta$-defensin 2 against nosocomial strains. Peptides 2010, 31, 1654-1660. [CrossRef]

35. Arimura, Y.; Ashitani, J.I.; Yanagi, S.; Tokojima, M.; Abe, K.; Mukae, H.; Nakazato, M. Elevated serum $\beta$-defensins concentrations in patients with lung cancer. Anticancer Res. 2004, 24, 4051-4058.

36. Baxter, A.A.; Poon, I.K.H.; Hulett, M.D. The plant defensin NaD1 induces tumor cell death via a non-apoptotic, membranolytic process. Cell Death Discov. 2017, 3, 16102. [CrossRef]

37. Bunney, T.; Katan, M. Phosphoinositide signalling in cancer: Beyond PI3K and PTEN. Nat. Rev. Cancer 2010, 10, 342. [CrossRef]

38. Thapa, N.; Tan, X.; Choi, S.; Lambert, P.F.; Rapraeger, A.C.; Anderson, R.A. The hidden conundrum of phosphoinositide signaling in cancer. Trends Cancer 2016, 2, 378-390. [CrossRef]

39. Mandal, K. Review of PIP2 in cellular signaling, functions and diseases. Int. J. Mol. Sci. 2020, 21, 8342. [CrossRef]

40. Phan, T.K.; Bindra, G.K.; Williams, S.A.; Poon, I.K.; Hulett, M.D. Combating human pathogens and cancer by targeting phosphoinositides and their metabolism. Trends Pharmacol. Sci. 2019, 40, 866-882. [CrossRef]

41. Al-Fahad, D. The possible role of PtdIns $(4,5) \mathrm{P}$ and $\operatorname{PtdIns}(3,4,5) \mathrm{P} 3$ at the leading and trailing edges of the breast cancer cell line. Iberoam. J. Med. 2021, 3, 26-32. [CrossRef]

42. Chen, C.; Wang, X.; Xiong, X.; Liu, Q.; Huang, Y.; Xu, Q.; Hu, J.; Ge, G.; Ling, K. Targeting type I $\gamma$ phosphatidylinositol phosphate kinase inhibits breast cancer metastasis. Oncogene 2015, 34, 4635-4646. [CrossRef] [PubMed]

43. Sumita, K.; Lo, Y.-H.; Takeuchi, K.; Senda, M.; Kofuji, S.; Ikeda, Y.; Terakawa, J.; Sasaki, M.; Yoshino, H.; Majd, N.; et al. The lipid kinase PI5P4K $\beta$ is an intracellular GTP sensor for metabolism and tumorigenesis. Mol. Cell. 2016, 61, 187-198. [CrossRef] [PubMed] 
44. Emerling, B.M.; Hurov, J.B.; Poulogiannis, G.; Tsukazawa, K.S.; Choo-Wing, R.; Wulf, G.M.; Bell, E.L.; Shim, H.-S.; Lamia, K.A.; Rameh, L.E.; et al. Depletion of a putatively druggable class of phosphatidylinositol kinases inhibits growth of p53-null tumors. Cell 2013, 155, 844. [CrossRef]

45. Yamaguchi, H.; Yoshida, S.; Muroi, E.; Kawamura, M.; Kouchi, Z.; Nakamura, Y.; Sakai, R.; Fukami, K. Phosphatidylinositol 4,5-bisphosphate and PIP5-kinase Ialpha are required for invadopodia formation in human breast cancer cells. Cancer Sci. 2010, 101, 1632-1638. [CrossRef]

46. Sarwar, M.; Khaja, A.S.S.; Aleskandarany, M.; Karlsson, R.; Althobiti, M.; Ødum, N.; Mongan, N.P.; Dizeyi, N.; Johnson, H.; Green, A.; et al. The role of PIP5K $1 \alpha /$ pAKT and targeted inhibition of growth of subtypes of breast cancer using PIP5K $1 \alpha$ inhibitor. Oncogene 2019, 38, 375-389. [CrossRef]

47. Semenas, J.; Hedblom, A.; Miftakhova, R.; Sarwar, M.; Larsson, R.; Shcherbina, L.; Johansson, M.E.; Härkönen, P.; Sterner, O.; Persson, J.L. The role of PI3K/AKT-related PIP5K1 $\alpha$ and the discovery of its selective inhibitor for treatment of advanced prostate cancer. Proc. Natl. Acad. Sci. USA 2014, 111, E3689-E3698. [CrossRef]

48. Sun, Y.; A Turbin, D.; Ling, K.; Thapa, N.; Leung, S.; Huntsman, D.G.; Anderson, R. Type I gamma phosphatidylinositol phosphate kinase modulates invasion and proliferation and its expression correlates with poor prognosis in breast cancer. Breast Cancer Res. 2010, 12, R6. [CrossRef]

49. Shin, Y.J.; Sa, J.K.; Lee, Y.; Kim, D.; Chang, N.; Cho, H.J.; Son, M.; Oh, M.Y.; Shin, K.; Lee, J.-K.; et al. PIP4K2A as a negative regulator of PI3K in PTEN-deficient glioblastoma. J. Exp. Med. 2019, 216, 1120-1134. [CrossRef]

50. Tavelis, C. Investigating the Potential Role of PIP4Ks in PI3K/Akt Signalling. 2012. Available online: https://www.research. manchester.ac.uk/portal/files/54535400/FULL_TEXT.PDF (accessed on 23 January 2022).

51. East, M.P.; Laitinen, T.; Asquith, C.R.M. PIP5K1A: A potential target for cancers with KRAS or TP53 mutations. Nat. Rev. Drug Discov. 2020, 19, 436. [CrossRef]

52. Goh, W.J.; Zou, S.; Ong, W.Y.; Torta, F.; Alexandra, A.F.; Schiffelers, R.; Storm, G.; Wang, J.-W.; Czarny, B.; Pastorin, G. Bioinspired cell-derived nanovesicles versus exosomes as drug delivery systems: A cost-effective alternative. Sci. Rep. 2017, 7, 14322. [CrossRef] [PubMed]

53. Blixt, Y.; Valeur, A.; Everitt, E. Cultivation of HeLa cells with fetal bovine serum or ultroser G: Effects on the plasma membrane constitution. In-Vitro Cell Dev. Biol. 1990, 26, 691-700. [CrossRef] [PubMed]

54. Choromańska, A.; Chwiłkowska, A.; Kulbacka, J.; Baczyńska, D.; Rembiałkowska, N.; Szewczyk, A.; Michel, O.; GajewskaNaryniecka, A.; Przystupski, D.; Saczko, J. Modifications of plasma membrane organization in cancer cells for targeted therapy. Molecules 2021, 26, 1850. [CrossRef] [PubMed]

55. Hollingsworth, M.A.; Swanson, B.J. Mucins in cancer: Protection and control of the cell surface. Nat. Rev. Cancer 2004, 4, 45-60. [CrossRef]

56. Bhatia, R.; Gautam, S.K.; Cannon, A.; Thompson, C.; Hall, B.R.; Aithal, A.; Banerjee, K.; Jain, M.; Solheim, J.C.; Kumar, S.; et al Cancer-associated mucins: Role in immune modulation and metastasis. Cancer Metastasis Rev. 2019, 38, 223-236. [CrossRef]

57. Elgundi, Z.; Papanicolaou, M.; Major, G.; Cox, T.R.; Melrose, J.; Whitelock, J.M.; Farrugia, B.L. Cancer metastasis: The role of the extracellular matrix and the heparan sulfate proteoglycan perlecan. Front. Oncol. 2020, 9, 1482. [CrossRef]

58. Fadeel, B.; Xue, D. The ins and outs of phospholipid asymmetry in the plasma membrane: Roles in health and disease. Crit. Rev. Biochem. Mol. Biol. 2009, 44, 264-277. [CrossRef]

59. Rivel, T.; Ramseyer, C.; Yesylevskyy, S. The asymmetry of plasma membranes and their cholesterol content influence the uptake of cisplatin. Sci. Rep. 2019, 9, 5627. [CrossRef]

60. Ivers, L.P.; Cummings, B.; Owolabi, F.; Welzel, K.; Klinger, R.; Saitoh, S.; O'Connor, D.; Fujita, Y.; Scholz, D.; Itasaki, N. Dynamic and influential interaction of cancer cells with normal epithelial cells in 3D culture. Cancer Cell Int. 2014, 14, 108. [CrossRef]

61. Knutton, S.; Jackson, D.; Graham, J.M.; Micklem, K.J.; Pasternak, C.A. Microvilli and cell swelling. Nature 1976, $262,52-54$. [CrossRef]

62. Szlasa, W.; Zendran, I.; ZalesiŃska, A.; Tarek, M.; Kulbacka, J. Lipid composition of the cancer cell membrane. J. Bioenerg. Biomembr. 2020, 52, 321-342. [CrossRef] [PubMed]

63. Preta, G. New insights into targeting membrane lipids for cancer therapy. Front. Cell Dev. Biol. 2020, 8, 876. [CrossRef] [PubMed]

64. Baricelli, J.; Rocafull, M.A.; Vázquez, D.; Bastidas, B.; Báez-Ramirez, E.; Thomas, L.E. $\beta$-defensin-2 in breast milk displays a broad antimicrobial activity against pathogenic bacteria. J. Pediatr. 2015, 91, 36-43. [CrossRef] [PubMed]

65. Francisco, G.C.; Georgina, E. Structural motifs in class I and class II plant defensins for phospholipid interactions: Intriguing role of ligand binding and modes of action. J. Plant Physiol. Pathol. 2017, 5, 2. [CrossRef]

66. Kovaleva, V.; Bukhteeva, I.; Kit, O.Y.; Nesmelova, I.V. Plant defensins from a structural perspective. Int. J. Mol. Sci. 2020, 21, 5307. [CrossRef]

67. Silva, P.M.; Gonãßalves, S.; Santos, N.C. Defensins: Antifungal lessons from eukaryotes. Front. Microbiol. 2014, 5, 97. [CrossRef]

68. Vongsa, R.A.; Zimmerman, N.P.; Dwinell, M.B. CCR6 regulation of the actin cytoskeleton orchestrates human beta defensin-2and CCL20-mediated restitution of colonic epithelial cells. J. Biol. Chem. 2009, 284, 10034-10045. [CrossRef]

69. Pinkerton, J.W.; Kim, R.Y.; Koeninger, L.; Armbruster, N.S.; Hansbro, N.G.; Brown, A.C.; Jayaraman, R.; Shen, S.; Malek, N.; Cooper, M.A.; et al. Human $\beta$-defensin-2 suppresses key features of asthma in murine models of allergic airways disease. Clin. Exp. Allergy 2021, 51, 120-131. [CrossRef] 
70. Schuerholz, T.; Brandenburg, K.; Marx, G. Antimicrobial peptides and their potential application in inflammation and sepsis. Crit. Care 2012, 16, 207. [CrossRef]

71. Nguyen, L.T.; Chau, J.K.; Perry, N.A.; De Boer, L.; Zaat, S.A.J.; Vogel, H.J. Serum stabilities of short tryptophan- and arginine-rich antimicrobial peptide analogs. PLoS ONE 2010, 5, e12684. [CrossRef]

72. Kamino, Y.; Kurashige, Y.; Uehara, O.; Sato, J.; Nishimura, M.; Yoshida, K.; Arakawa, T.; Nagayasu, H.; Saitoh, M.; Abiko, Y. HBD-2 is downregulated in oral carcinoma cells by DNA hypermethylation, and increased expression of hBD-2 by DNA demethylation and gene transfection inhibits cell proliferation and invasion. Oncol. Rep. 2014, 32, 462-468. [CrossRef] [PubMed]

73. Sun, T.; Luo, Y.; Wang, M.; Xie, T.; Yan, H. Recombinant oncolytic vaccinia viruses expressing human $\beta$-defensin 2 enhance anti-tumor immunity. Mol. Ther.-Oncolytics 2019, 13, 49-57. [CrossRef] [PubMed] 